\title{
THE EFFECT OF STEPWISE EXERCISE ON VENTILATORY AND RESPIRATORY FUNCTIONS IN SPORT HORSES
}

\author{
J. HANÁK \\ Department of Diagnosis, Therapy and Control of Animal Diseases, University of Veterinary \\ Science, 61242 Brno
}

Received March 1, 1989

\begin{abstract}
Hanák J.: The Effect of Stepwise Exercise on Ventilatory and Respiratiory Functions in Sport Horses. Acta vet. Brno, 59, 1990: 139-150.

Breathing frequency, tidal volume, pulmonary ventilation, oxygen consumption, carbon dioxide output and the so called ventilatory equivalent and respiratory quotient were radiotelemetrically studied in 12 horses, ranging in age from 4 to 12 years, at stepwise exercise.

The dependence of pulmonary ventilation and of oxygen consumption on the speed of exercise was found to be linear whereas that of carbon dioxide output on the horse speed quadratic. The values of breathing frequency, tidal volume and ventilatory equivalent are dependent on the horse locomotion mechanics in individual types of exercise. Respiratory quotient changing during stepwise exercise indicates a character of changes in energy metabolism and acid-base balance of the interior environment. Respiratory quotient higher than 1.0 indicated probably the approach to the maximal oxygen consumption and to the intensive anaerobic energy production at work effort of over $70 \%$ WEmax (anaerobic threshold).
\end{abstract}

Walk, trot, canter, gallop

Efforts of recent years to increase specific performance of sport and race horses all over the world have necessitated well-intentioned attitudes towards means and methods of a training process. This progress calls also for an improvement of veterinary control in the field of preventive diagnostics, therapy and control directly in race and sport stables. The diagnosis of often very delicate functional and morphological changes in organs and organ systems of a trained individual necessitates an introduction of a whole series of modern diagnostical methods into an equine clinical practice. The diagnosis of ventilatory and respiratory functions in an exercising animal represents one of these methods.

Respiratory apparatus ensures the uptake into the organism of oxygen and output of carbon dioxide. Its efficiency is generally given by ventilatory parameters expressed by the Fick equation (Handzo et al. 1980):

$$
\mathrm{V}_{2}=\mathrm{V}_{\mathrm{E}} \cdot\left(\mathrm{F}_{\mathrm{IO}_{2}}-\mathrm{FEO}_{2}\right)=\mathrm{V}_{\mathrm{T}} \cdot \mathrm{f}_{\mathrm{b}} \cdot\left(\mathrm{F}_{\mathrm{IO}_{2}}-\mathrm{F}_{\mathrm{EO}_{2}}\right) .
$$

This equation expresses the relationship between the oxygen uptake $\left(\mathrm{V}_{\mathrm{O}_{2}}\right)$, the value of the minute pulmonary ventilation $\left(V_{E}\right)$, or tidal volume $\left(V_{T}\right)$, and the breathing frequency $\left(f_{\mathfrak{b}}\right)$ and the utilization of oxygen from atmosphere $\left(\mathrm{F}_{\mathrm{IO}_{2}}-\mathrm{F}_{\mathrm{EO}_{2}}\right)$. In the increase of pulmonary ventilation during exercise both an acceleration of breathing frequency and an increase of tidal volume participate. Studies on mechanics of respiration and breathing work effort at rest ( $\mathrm{Hush} \mathrm{1974;} \mathrm{Meix-}$ ner 1976; Attenburrow 1982) have shown that to every volume of minute pulmonary ventilation correspond a certain optimal breathing frequency and a certain tidal volume, at which the breathing effort of the horse is the lowest and breathing energetically most efficient. At exercise, this principle of economy is, however, suppressed because breathing frequency and tidal volume are greatly influenced by a locomotion rhythm and mechanics of the horse, or by the stride fre- 
quency $\left(f_{s}\right)$, particularly at exercise of higher intensity, as was demonstrated e. g. by Attenburrow $(1982,1983)$ or Hörnicke and Meixner $(1977,1978)$. Breathing in horses is thus greatly influenced not only by the type of exercise (walk, trot, gallop, canter) but also by its intensity, macroclimate effects of the external environment, individual habits of every horse stereotypes, apart from pathological causes (Littlejohn et al. 1983; Pollman and Hörnicke 1987). One of the factors determining the rate of breathing work could also be the resistance of airways to the airflow. The increased activity of the sympathicus and higher levels of blood catecholamines during exercise imply the decrease of flow resistance of airways (Gillespie 1974). This favourable effect is, however, dependent on other factors, e. g. on temperature and humidity of inspired air or other external factors (Mansmann et al. 1974; Carlson 1979; Gillespie and Pascoe 1983; Attenburrow et al. 1983).

The increase of minute pulmonary ventilation at stepwise exercise in horses on treadmill is roughly linear with the exercise intensity from the rest values of $65-90 \mathrm{l} / \mathrm{min}$ to over $11001 / \mathrm{min}$ (Thomas and Fregin 1981). At submaximal and maximal exercise intensity the increase of minute pulmonary ventilation is disproportionally rapid (Karlsen and $\mathrm{Nadaljak} \mathrm{1964;} \mathrm{Hörnicke}$ and Meixner 1977; 1978; Hörnicke et al. 1987). This phenomenon is not the consequence of the impared ventilatory eff iciency of lungs at the high intensity exercise, as was previously assumed, but it is a sign of the ventilatory compensation of metabolic acidosis at which the volatile acid content in blood decreases by the increased carbon dioxide output by lungs. The pulmonary ventilation is thus, in spite of exercise intensity, in a linear positive correlation to the carbon dioxide output (Muir et al. 1975). Expired carbon dioxide originates mostly from muscular metabolism (aerobic breakdown of lipids and glycogen) and also from the blood, particularly from blood bicarbonates from which it is released with the increasing lactacidaemia (anaerobic glycolysis). The ventilation increase in intensive anaerobic exercise is thus associated with the ventilatory compensation of metabolic acidosis by way of the output of a necessary amount of carbon dioxide (Hörnicke et al. 1987).

The utilization of oxygen from atmosphere $\left(\mathrm{F}_{\mathrm{IO}_{2}}-\mathrm{F}_{\mathrm{EO}_{2}}\right)$ is also changing with the increasing exercise intensity (Hörnicke et al. 1983). It can thus be generally assumed that at moderate and medium exercise the increase in oxygen utilization in lungs parallel that of ventilation and carbon dioxide output (aerobic metabolism). On the contrary, at submaximal and maximal exercise intensity the oxygen utilization from atmosphere decreases below the rest level (anaerobic metabolism) and high ventilation is used predominantly for the compensation to the metabolic acidosis by way of giving off the necessary amount of carbon dioxide (Muir et al. 1975; Thomas and Fregin 1981; Hörnicke et al. 1987).

The increase in oxygen uptake $\left(\mathrm{V}_{\mathrm{O}_{2}}\right)$ is linear with that in exercise intensity up to the maximal oxygen consumption $\left(\mathrm{V}_{2} \mathrm{max}\right.$ ) and further no more changes with the increasing exercise intensity are observed (Thomas et al. 1980; Thomas and Fregin 1981; Taylor and Heglund 1982; Taylor et al. 1982). The maximal oxygen consumption in horse was reported to be $64.2 \mathrm{l} / \mathrm{min}$ (Engelhardt 1977). Thomas et al. (1980) found the value of $59.61 / \mathrm{min}$ at swimming exercise of horses and Thomas and Fregin (1981) $39 \mathrm{l} / \mathrm{min}$ at short term exercise of maximal intensity. It follows that during high intensity exercise oxygen uptake decreases, or a greater proportion of anaerobic metabolism asserts itself in the time of tissue oxygen deficit.

The above presented short literature review outlines problems that have been the aim of the present work: to monitor the dynamics of ventilatory and respiratory functions in horses at four types of stepwise standard exercise differing not only in intensity but also in the mechanics of locomotion.

\section{Materials and Methods}

Altogether 12 sport horses, ranging in age from 4 to 12 years, weighing in average $477.5 \pm \mathrm{kg}$, were used in the experiment. Horses were ridden by $70-80 \mathrm{~kg}$ weighing riders and were subjected to a $3.000 \mathrm{~m}$ exercise at walk, trot and gallop. The speed of these rates represented in every horse 15,30 and $50 \%$ of the horse's individual utmost speed measured in a pre-trial at the $400 \mathrm{~m}$ distance. Further 6 horses selected from this set were subjected to further exercise $(1500 \mathrm{~m})$ on a following day, the speed corresponding to $70 \%$ of the maximum work effort of every horse (WE\%max).

Using a telemetrical method (Hanák and Zakopal 1979; Hanák 1980), heart rate $\left(f_{H}\right)$, breathing frequency $\left(f_{\mathfrak{h}}\right)$ and tidal volume $\left(V_{T}\right)$ were monitored at rest and at all individual types of exercise. Stride frequency $\left(f_{\mathbf{S}}\right)$ was monitored by a visual reading of the number of steps/jumps per time unit. Multiplying $f_{b}$ and $V_{T}$ values the minute pulmonary ventilation $\left(V_{E}\right)$ was calculated and tabularly corrected to the BTPS (body temperature - atmospheric pressure - water saturated) conditions, i. e. according to the rectal temperature, atmospheric pressure and vapour pressure 
measured by thermohydrometer. Using a Scholander device the percentage of oxygen uptake, carbon dioxide output and the respiratory quotient (RQ) were determined from the analysis of atmospherical and expired air samples collected from the respiration mask by a special fiveport collector. These respiration values were then tabularly corrected to the STPD conditions (standard temperature - pressure - dry). From the values obtained the value of oxygen uptake $\left(\mathrm{V}_{2}\right)$ carbon dioxide output $\left(\mathrm{V}_{\mathrm{CO}_{2}}\right)$ and the so called ventilatory equivalent (VE) expressing the amount of air ventilated through lungs from which the organism takes 1 litre of oxygen, were determined. $\mathrm{RQ}$ was also measured in 10 minutes pending the end of each exercise.

The results were statistically processed and graphically evaluated using a model $9810 \mathrm{~A} \mathrm{Hewlett-}$ -Packard computer. The method of a simple analysis of variance and Duncan's test were used to analyze the statistical significance of set differences. The closeness of the relationship was expressed by a coefficient of correlation $(r)$, the dependence between the studied values by regression equations.

\section{Results}

Stride and breathing frequencies increase almost linearly with the increasing speed of exercise as can be seen from Fig. 1 . At the walk and trot $f_{s}$ and $f_{b}$ are, however, asynchronous and synchronization occurs only at both gallopping exercises, i. e. over $50 \% \mathrm{WE}_{\max }$. It appears to be interesting that the value of $\mathrm{f}_{\mathrm{b}}$ is generally higher at the walk whereas that of $f_{s}$ at the trot. Tidal volume increases proportionally to the increasing speed both at the walk and trot (Fig. 1). When changing to the canter a very slight increase in $V_{\mathrm{T}}$ was observed, however, markedly with the increasing speed at the gallop at $70 \% \mathrm{WE}$ max.

The dependence of minute pulmonary ventilation $\left(V_{E}\right)$ upon the speed of exercise was found to be linear, as can be seen in Fig. 2, and is expressed by a regression equation of the straight line (Table 1). Statistically highly significant $(P<0.01)$ and a very close positive correlation between $V_{E}$ and speed is given by a coefficient $r=0.99$. Out of the values calculated, a priority attention should be paid to the oxygen uptake $\left(\mathrm{V}_{\mathrm{O} 2}\right)$ that expresses the multiplication of ventilatory values $f_{b}$ and $V_{T}$ and the utilization of oxygen from inspired air $\left(\mathrm{F}_{\mathrm{IO}_{2}}-\mathrm{F}_{\mathrm{OE}_{2}}\right)$. Statistically highly significant positive correlation $(P<0.01)$ between $V_{\mathbf{O}_{2}}$ and the speed of exercise ( $\mathrm{v}$ ) is very close $(r=0.99)$. The dependence is linear (Fig. 2) and is expressed by a regression equation of the straight line (Table 1). The dependence of carbon dioxide output $\left(\mathrm{V}_{\mathrm{CO}_{2}}\right)$ upon the speed is, however, quadratic (Fig. 2) and is expressed by a regression parabolic equation and by a close positive correlation (Table 1).

The utilization of oxygen from inspired air $\left(\mathrm{F}_{\mathrm{IO}_{2}}-\mathrm{F}_{\mathrm{EO} 2}\right)$, carbon dioxide output into expired air $\left(\mathrm{F}_{\mathrm{ECO} 2}-\mathrm{F}_{\mathrm{ICO}_{2}}\right)$ and the respiratory quotient $(\mathrm{RQ})$ at rest, at exercises of various intensities and at repaying the oxygen debt between exer-

Table 1

Dependence of $\mathrm{V}_{\mathrm{E}}, \mathrm{V}_{\mathrm{O}_{2}}$ and $\mathrm{V}_{\mathrm{CO}_{2}}$ upon the exercise speed (v) expressed by regression equations and coefficients of correlation

\begin{tabular}{|l|l|l|}
\hline \multicolumn{1}{|c|}{ Dependence } & $\mathbf{r}$ & $\mathbf{P}<$ \\
\hline $\mathrm{V}_{\mathrm{E}}=113.58+2.32 . \mathrm{v}$ & 0.99 & 0.01 \\
$\mathrm{~V}_{\mathrm{O}}=0.79+0.10 . \mathrm{v}$ & 0.99 & 0.01 \\
$\mathrm{~V}_{\mathrm{CO}=1}=1.5274+0.5565 . \mathrm{v}+0.0009 . \mathrm{v}^{2}$ & 0.97 & 0.01 \\
\hline
\end{tabular}



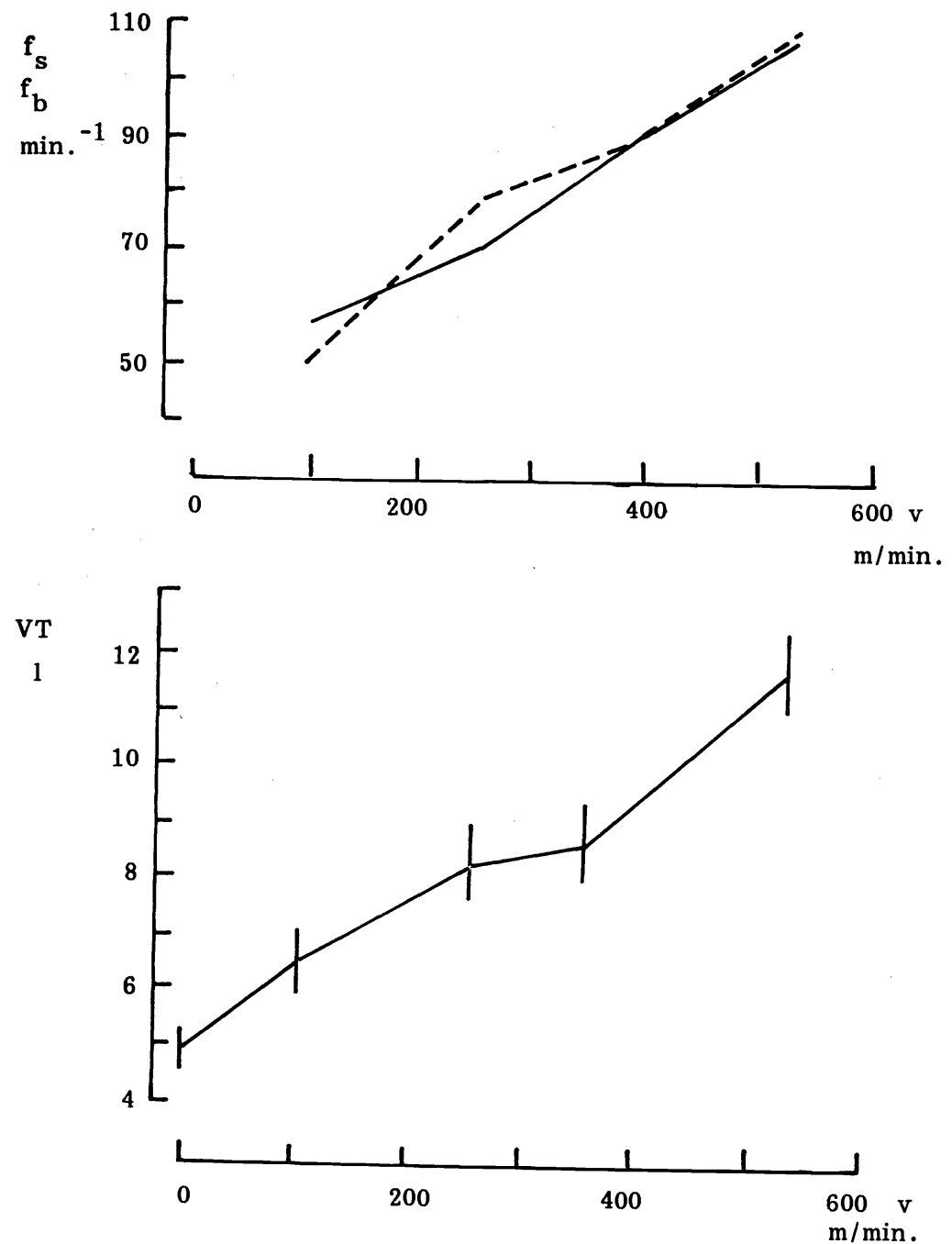

$\begin{array}{ccccc}\text { Rest } & \text { Walk } & \text { Trot } & \text { Canter } & \text { Gallop } \\ 0 & 15 \% & 30 \% & 50 \% & 70 \% \text { WE }\end{array}$

Fig. 1. Changes in stride frequency $\left(f_{S}\right)$, breathing frequency $\left(f_{b}\right)$ and tidal volume $\left(V_{T}\right)$ at stepwise exercise

cises, are presented in Fig. 3. It follows that after a temporary lowering of oxygen utilization, carbon dioxide output and RQ at the walk with $15 \%$ WE max an increase of these respiratory functions occurs with the growing effort intensity. At the gallop ( $70 \%$ WE max) the carbon dioxide output is already higher than oxygen utilization and RQ thus exeeds the value of 1.0. During recovere between two exercises, i. e. repaying the oxygen debt, $R Q$ is always higher than its value at previous exercise. 
The value of ventilatory equivalent (VE), expressing the amount of air ventilated through lungs, out of which the animal utilides 1 litre of oxygen, informs about the efficency of respiratory functions during exercise. From Fig. 4 follows that VE after a temporary but statistically significant increase $(P<0.01)$ at the walk up to $15 \%$ WE max decreases rapidly and significantly $(P<0.01)$ at the
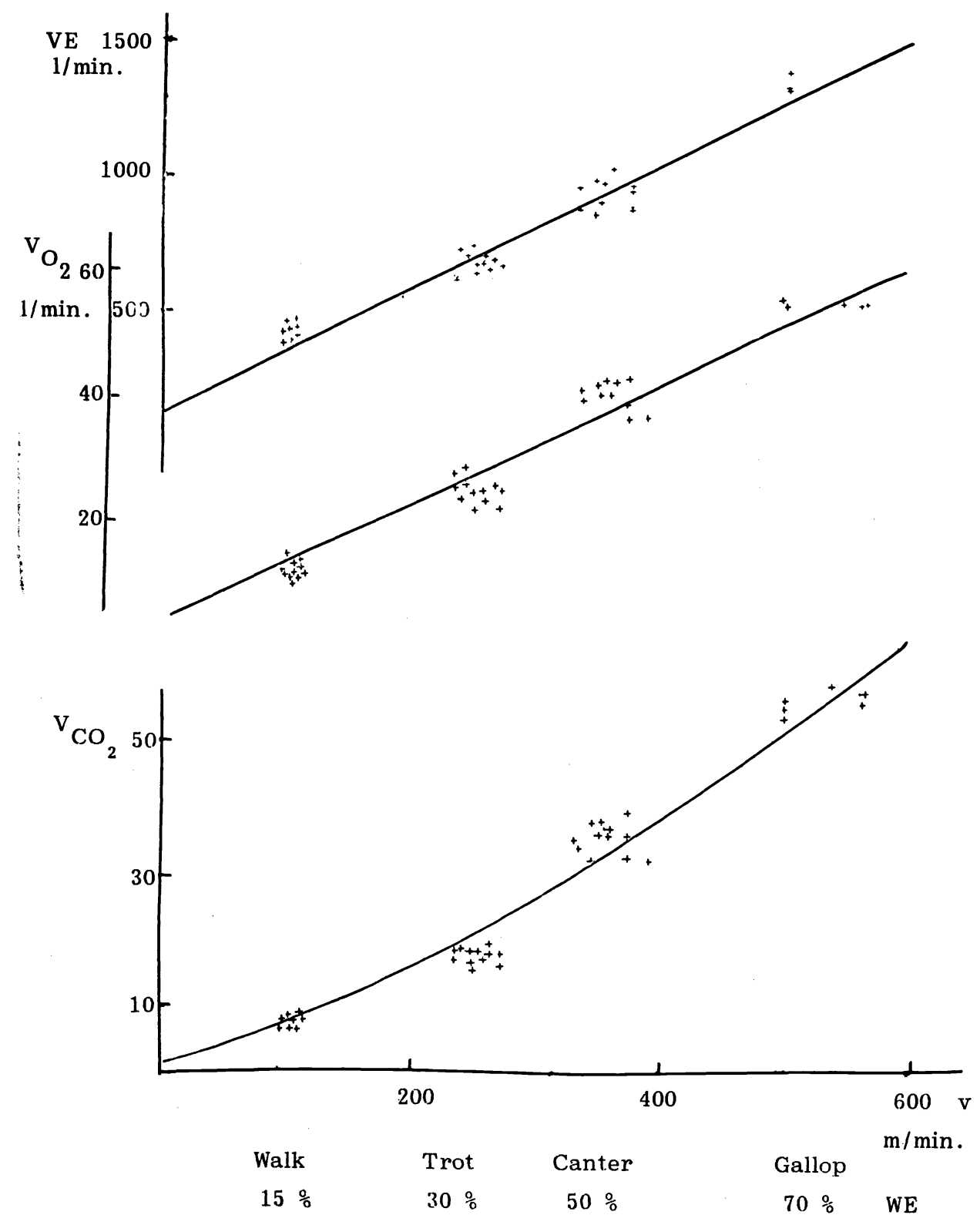

Fig. 2. Dependence of minute pulmonary ventilation $\left(\mathrm{V}_{\mathrm{E}}\right)$, oxygen uptake $\left(\mathrm{V}_{2}\right)$ and carbon dioxide output $\left(\mathrm{V}_{\mathrm{CO}_{2}}\right)$ during exercise upon the speed (v) 

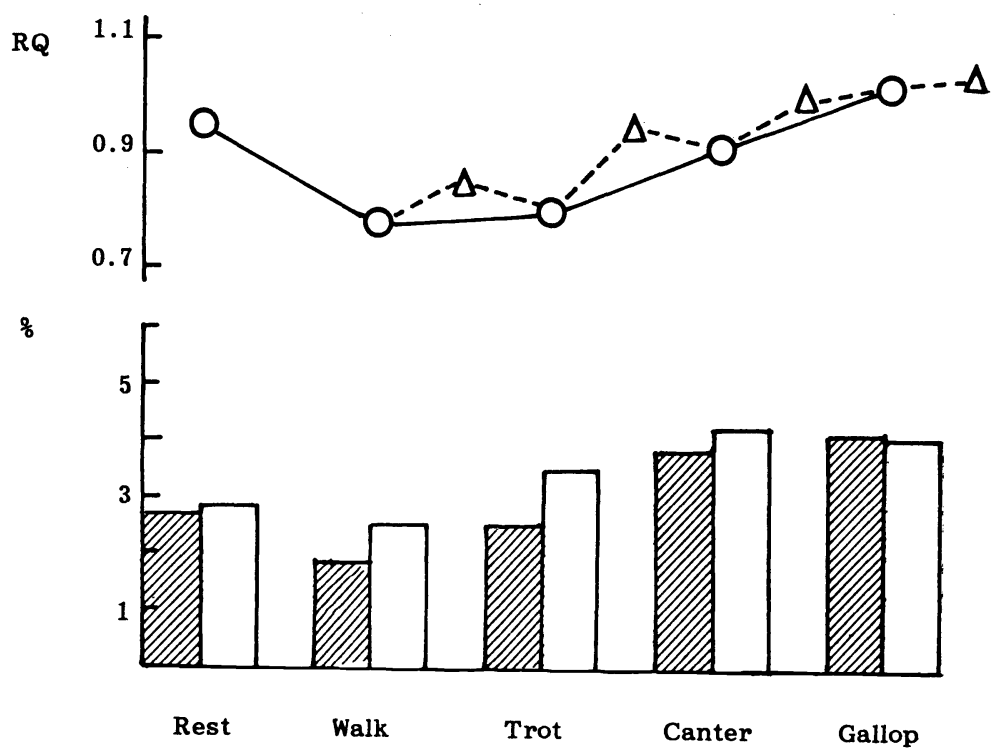

Fig. 3. Oxygen utilization from inspired air $\left(\mathrm{F}_{\mathrm{IO}_{2}}-\mathrm{F}_{\mathrm{EO}_{2}}\right)$ and carbon dioxide output by expired air $\left(\mathrm{F}_{\mathrm{ECO}_{2}}-\mathrm{F}_{\mathrm{ICO}_{2}}\right)$ and respiratory quotion (RQ) at rest, at exercise of various intensities and during recovery after exercise when repaying the oxygen debt

- $\mathrm{F}_{\mathrm{ECO}_{2}}-\mathrm{F}_{\mathrm{ICO}_{2}}, \mathrm{~F}_{\mathrm{IO}_{2}}-\mathrm{F}_{\mathrm{EO}}, \mathrm{O} \mathrm{R}$ of exercise, $\triangle \mathrm{RQ}$ of recovery

trot and gallop compared with the rest and walk values. The decrease of VE at both canter and gallop is in comparison with the trot also statistically highly significant $(P<0.01)$. At faster gallop $(70 \%$ WE max) the VE slightly increases compared to a slower canter $(50 \% \mathrm{WE}$ max), this increase being, however, statistically non-significant $(P>0.05)$. The decrease in VE during stepwise exercise signifies a higher efficiency of respiratory functions in oxygen uptake with the increasing speed of exercise (v) and in the work effort (WE).

\section{Discussion}

From our studies follows that ventilatory parameters during stepwise exercise have shown a different dynamics of changes and that at individual types of exercise they were influenced to a great extent by the mechanics of locomotion, or by stride frequency $\left(f_{s}\right)$. The mechanics of horse breathing substantially differs from that in man. Bipedal locomotion of the running man influences in a minimum way the mechanics of the chest movement and therefore an athlete can change not only breathing frequency but also the size of tidal volume as desired. Breathing in man is thus independent of the step frequency (Fedak and Seeherman 1979). Mechanics of locomotion and breathing in a horse at individual rates of exercise greatly influence particularly the way of the minute pulmonary ventilation increase. At the walk when $f_{b}$ is greater than $f_{s}\left(f_{b}>f_{s}\right)$ the tidal volume is also relatively lower whereas at the trot $f_{b}<f_{s}$ and thus a relatively larger tidal volume. At both galloping exercises $f_{b}=f_{s}$. Faster gallop at $70 \%$ WE max uses a longer gallop jump and stretching of the body during the longer phase of taking-off and 


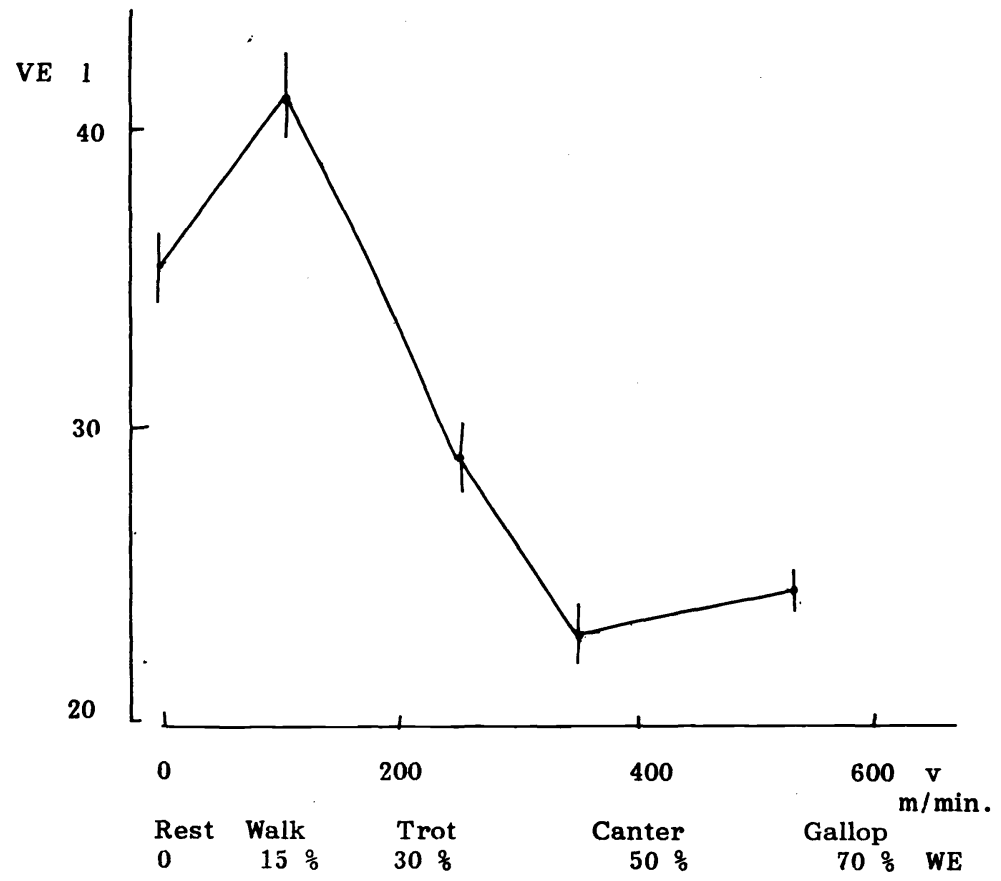

Fig. 4 Dependence of ventilatory equivalent (VE) on the exercise intensity (v)

and flight, it extends the thorax and enables deeper inspirium with larger tidal volume. The impact of the forelegs on the thorax and the phase of landing helps expirium (Attenburrow 1982; 1983). On the contrary, slow gallop at $50 \%$ WE max does not enable such a deep ventilation of dead space since it does not utilize the mechanics of locomotion to deepen breathing that is provided by a more active participation of breathing muscels.

At submaximal exercise in man the tidal volume represents about $50 \%$ of vital lung capacity (Wasserman and Whipp 1975) whereas in a horse this volume seldom exceeds one third of the vital lung capacity as was referred by Hörnicke et al. $(1983 ; 1987)$, Poolmann and Hörnicke $(1984 ; 1987)$. To reach a better alveolar ventilation in exercise the horse has to increase the total pulmonary ventilation more than athletes do. In spite of the high proportion of dead space ventilation (Poolmann and Hörnicke 1984; Pelletier et al. 1987) the breathing efficiency in horses is not less efficient than in highly trained athletes (Engelhardt 1977). On the contrary, as could be observed in our group of horses, in case of the dynamics of changes in oxygen utilization from inspired air, $V_{\mathrm{O}_{2}}, \mathrm{~V}_{\mathrm{CO} 2}, \mathrm{RQ}$ and VE, the oxygen uptake is limited more by the alveolar ventilation and gas diffusion across alveocapillary membrane than by own pulmonary ventilation. This unique capability of a horse in the exchange of respiratory gases is proved also by the fact that a horse can increase its maximum oxygen uptake as much as 40-times compared with the rest values whereas man only 20-times (Engelhardt 1977; McMicken 1983). It means than in the high efficiency of the respiratory system of a horse during gas exchange the diffusing capacity of the lungs partici- 
pates first of all (Gillespie 1974; Gillespie and Pascoe 1983), its clinical manifestation being not only the oxygen uptake from inspired air and carbon dioxide output but also the ventilatory equivalent (VE).

Ventilatory equivalent decreases at the galloping exercises when compared with the rest value in average by $30 \%$ which represent also a percentage increase in in gas diffusion across the alveocapillary membrane. Low VE values at the canter over $50 \%$ WE max suggest always a favourable respiration. On the contrary, high VE values suggest respiration that is inhibited and are the signs of poor economy with respiratory gases. The increase in VE during the walk when high breathing frequency and small tidal volume caused a limited alveolar ventilation and impaired gas diffusion across the alveocapillary membrane can also be assessed in the same way. This entrapped respiration during the walk should correspond from the clinical point of view to the so called freuquent dyspnea that could also have an emotional character (higher excitation of horses at the walk). A slight increase in VE at fast gallop ( $70 \%$ WE max) does not of course, mean impairment of respiratory function when compared with the slow canter (50\% WE max) but it might express the approaching at the maximum oxygen consumption at higher levels of exercise over $70 \%$ WE max. These changes in VE correspond closely not only to the increase of oxygen uptake in dependence on the exercise intensity but also with other parameters of respiration as oxygen utilization, carbon dioxide output and $R Q$.

The oxygen utilization from inspired air $\left(\mathrm{F}_{\mathrm{IO}_{2}}-\mathrm{F}_{\mathrm{EO}_{2}}\right)$ during individual exercises copies by its dynamics directly the course of VE changes. Entrapped respiratory functions at the walk are manifested both by a worsened oxygen utilization from inspired air but also by a lower carbon dioxide output. With the increasing intensity of exercise at the trot and canter the oxygen utilization and carbon dioxide output increase which is a sign of a higher respiration efficiency at these types of exercise. Carbon dioxide output at the trot up to $30 \%$ WE max does not, however, exceed the rest value and characterizes a certain retention of carbon dioxide in organism. At the fast gallop over $70 \%$ WE max the carbon dioxide excretion further rapidly increases but the oxygen utilization decreases. This discrepancy between the oxygen utilization and carbon dioxide output at the fast gallop demonstrates that at this type of exercise a failure of respiratory functions does not occur but that it is a sign of approaching the maximum oxygen consumption and of a change to a high proportion of anaerobic metabolism. When arriving at the maximum oxygen consumption $\left(\mathrm{V}_{\mathrm{O} 2} \mathrm{max}\right)$ the oxygen utilization $\left(\mathrm{F}_{\mathrm{IO}_{2}}-\right.$ $-\mathrm{F}_{\mathrm{EO} 2}$ ) with further growing ventilation decreases in such an extent that total $\mathrm{V}_{\mathrm{O}_{2}}$ can even decrease. Thus a full development of anaerobic metabolic processes with a drastic lactate production, so called anaerobic threshold, is enabled (Persson 1983). The increasing pulmonary ventilation then purposefully participates in the carbon dioxide output in order to compensate metabolic acidosis during exercise.

When evaluating the dynamics of RQ changes during individual exercises and in recovery periods an apparent RQ decrease at the walk and trot up to $30 \%$ WE max can be observed if compared with rest values. Whereas at the walk the low $R Q$ is caused first of all by the lowered carbon dioxide output the decreased RQ at the trot can be attributed to an increased oxygen utilization from inspired air. It can thus be suggested that at the walk the low $R Q$ could demonstrate the emotional frequent hyperventilation in entrapped respiratory functions and not the retention of carbon dioxide in organism. On the contrary, at the trot with a good 
efficency of ventilatory and respiratory functions the low RQ might suggest a certain retention of carbon dioxide towards the bicarbonate synthesis and not its aeration by intensive hyperventilation as was observed when studying the blood acid-base balance in our previous work (Hanák and Zakopal 1985; Hanák 1987). Both above mentioned cases were concerned with exercises with a predominating proportion of aerobic energy metabolism. Energy obtained by an oxidative phospohorylation is released first of all by the breakdown of lipids or nonesterified fatty acids that can also be confirmed by $R Q$ of 0.8 .

High RQ and a quadratic increase in carbon dioxide output at both galloping exercises are predominantly the demonstration of changes in energy metabolism during the breakdown of high energy substrates, the final products of which are carbon dioxide and $\mathrm{H}_{2} \mathrm{O}$ (aerobic metabolism of lipids and glycides), and during the metabolic acidosis formed through anearobic glycolysis, where the lactate production is settled by a bicarbonate system with the release of a great amount of carbon dioxide without a corresponding uptake of oxygen

$$
\left(\mathrm{Na}^{+} \mathrm{HCO}_{3}{ }^{-}+\mathrm{H}^{+} \text {lactate }{ }^{-}=\mathrm{Na}^{+} \text {lactate }{ }^{-}+\mathrm{H}_{2} \mathrm{CO}_{3}=\mathrm{H}_{2} \mathrm{O}+\mathrm{CO}_{2}\right) \text {. }
$$

RQ higher than 1.0 at the gallop of $70 \%$ WE max could also be the indicator of the maximum oxygen consumption (Wasserman and Whipp 1975; Ewans and Rose 1987) or of exceeding the anaerobic threshold (McMicken 1983).

The high RQ (over 1.0) during the repayment of oxygen debt after the gallop had finished demonstrates first of all a considerable airing of carbon dioxide from the lungs during the compensation to the metabolic acidosis. RQ values following the walk and trot exercises (0.85 and 0.94 , resp.) could demonstrate the $\mathrm{CO}_{2}$ output that was produced at the beginning of work as a "carbon dioxide debt" due to which physiological hypercapnia appears. This hypercapnia is a reflex stimulus for a higher ventilation. High $R Q$ at rest in standing horses $(0.95)$ characterizes emotional hyperventilation prior to the beginning of an exercise.

Summarizing the obtained knowledge about ventilatory and respiratory functions in sport horses during individual types of exercises in comparison with a human being we can conclude that the increase in oxygen uptake in man is provided first of all by a high efficiency of ventilatory functions with an economy in breathing work, economical breathing with a larger tidal volume that enable to decrease the volume of the dead space and to increase alveolar ventilation. In sport horses, due to the mechanics of locomotion, and especially at the gallops, the ventilatory functions are inhibited and their certain insufficiency is compensated by high effectiveness of respiratory functions, particularly by an increased gas diffusion across the pulmonary alveocapillary membrane, i. e. by an increased diffusing capacity of lungs. Whereas at the trot the ventilatory and respiratory functions are in equilibrium, at the walk both the ventilatory and respiratory functions are inhibited and the oxygen uptake is impaired. High effectiveness of respiratory functions at exercises over $30 \%$ WE max demonstrate in our cases a hypothesis that horses, in contrast to man, have a much higher reserve in the oxygen uptake due to the increase in gas diffusing capacity across the alveocapillary membrane and to oxygen transport by the cardiovascular system whereas in man the increase of oxygen uptake is provided mainly by ventilatory functions of the respiratory system. 


\section{Vliv stupňované pohybové zátěže na ventilační a respirační funkce u sportovních koní}

U 12 sportovních koní byla $\mathrm{v}$ průběhu stupňované pohybové zátěže sledována radiotelemetricky dechová frekvence, dechový objem, plicní ventilace, spotřeba kyslíku, výdej $\mathrm{CO}_{2}$ a tzv. ventilační ekvivalent a respirační kvocient.

Bylo zjištěno, že závislost plicní ventilace a spotřeby $\mathrm{O}_{2}$ na rychlosti pohybu je lineární, zatímco závislost výdeje $\mathrm{CO}_{2}$ na rychlosti koní je kvadratická. Velikost dechové frekvence, dechového objemu a ventilačního ekvivalentu je závislá na mechanice pohybu koni $\mathrm{v}$ jednotlivých typech zátěže. Změny respiračního kvocientu $\mathrm{v}$ průběhu stupňované zátěže indikují charakter změn v energetickém metabolismu a acidobasické rovnováze vnitřního prostředí. RQ vyšši než 1,0 je také pravděpodobně i indikátorem dosažení kyslíkového stropu a intensivní anearobní energetické produkce při zátěžích o pracovním úsilí nad $70 \%$ maxima.

\section{Влияние үвеличивающейся двигательной нагрузки на Функции вентиляции и респирации скаковых пошадей}

На 12 скаковых лошадях в ходе үвеличивающейся двигательной нагрузки радиотелеметрически исследовали частоту дыхания, объем дыхания, вентиляцию легких, расход кислорода, выдачу $\mathrm{CO}_{2}$ и так называемый вентиляционный эквивалент и дыхательный коэффициент.

Было установлено, что зависимость вентиляции легких и расхода $0_{2}$ от скорости движения является линейной, между тем как зависимость выдачи $\mathrm{CO}_{2}$ от скорости лошадей - квадратичной. Величины частоты дыхания и объема дыхания, а также эквивалента вентиляции зависят от механики движения лошадей в отдельных типах нагрузки. Изменения дыхательного коэффициента в ходе усиливающейся нагрузки свидетельствуют о характере изменений энергетического метаболизма и кислотно-основного равновесия внутренней среды. RQ больше 1,0 является, по-видимому, также индикатором достижения кислородного предела и интенсивной анаэробной энергетической продүкции при нагрузке с трудовым усилием, превышающем $70 \%$ максимума.

\section{References}

ATTENBURROW, D. P.: Time relationship between the respiratory cycle and limb cycle in the horse. Equine veter. J., 14, 1982: 69-72.

ATTENBURROW, D. P.: Respiration and locomotion. In: Equine Exercise Physiology. Snow, D. H., Persson, S. G. B., Rose, R. J. (Eds), Cambridge, Granta, Burlington Press 1983; pp. $17-22$.

ATTENBURROW, D. P.-FLACK, F. C.-HÖRNICKE, H.-MEIXNER, R.-POLLMANN, U.: Respiratory airflow and sound intensity. In: Equine Exercise Physiology. Snow, D. H., Persson, S. G. B., Rose, J. R. (Eds), Cambridge, Granta, Burlington Press 1983: 23-26.

CARLSON, G. P.: Physiologic responses to endurance exercise. Proc. Amer. Assoc. Equine Practnrs., 25, 1979: 459-468.

EVANS, D. L.-ROSE, R. J.: Maximum oxygen uptake in racehorses: changes with training state and prediction from submaximal cardiorespiratory measurements. In: Equine Exercise Physiology 2. Gillespie, J. R., Robinson, N. E. (Eds), Davis, ICEEP Publications 1987, pp. $52-67$.

ENGELHARDT, W.: Cardiovascular effects of exercise and training in horses. Adv. veter. Sci. comp. Med., 21, 1977: 173-204. 
GILLESPIE, J. R.: The role of respiratory system during exertion. J. S. Afr. veter. Assoc., 45 $1974 ; 305-309$.

GILLESPIE, J. R.-PASCOE, J. R.: Respiratory function in the exercising horse: A review. In: Equine Exercise Physiology. Snow, D. H., Persson, S. G. B., Rose, J. R. (Eds), Cambridge, Granta, Burlington Press 1983, pp. $1-6$.

FEDAK, M. A.-SEEHERMAN, H. J.: Reappraisal of energetics of locomotion shows identical cost in bipeds and quadrupeds including ostrich and horse. Nature, 282, 1979: 713-716.

HANÁK, J.: Bioradiotelemetrie a elektrokardiogram u koní při zátěži. Assoc. Professor Thesis. Brno 1980, $192 \mathrm{p}$.

HANÁK, J.: Studium dynamiky metabolických procesů u sportovních a dostihových koni. D. Sc. Thesis. Brno 1987, 360 p.

HANÁK, J. - ZAKOPAL, J.: The system of spiroergometry in equestrian horses in movement. In: Proc. 21st World veter. Congr., Moscow 1979, 6:14.

HANÁK, J. - ZAKOPAL, J.: Systém kontroly zdraví v chovech sportovních koní - systém elektrokardiografie a bioradiotelemetrie. Project report, Brno 1980, 94 p.

HANÁK, J. - ZAKOPAL, J.: Výzkum poruch metabolismu ve vztahu k výkonnosti koní. Research report, Brno 1985, $86 \mathrm{p}$.

HANDZO, P.-MÁCEK, M.-DRAŽIL, V.-HÁJKOVÁ, M.: Tělovýchovné lékařství. Praha, Avicenum, 1980, 174 p.

HÖRNICKE, H.-MEIXNER, R.: Depth and frequency of breathing in exercising horses. (Abstract). Proc. int. Union Physiol. Sci., 13, 1977, p. 332.

HÖRNICKE, H.-MEIXNER, R.: Die Lungenventilation des Pferdes bei der Bewegung in Schritt, Trab und Gallop - ein Beitrag zur vergleichenden Leistungsphysiologie. (Abstract). Verh. Dtsch. Zool. Gessel., 1978, p. 285.

HÖRNICKE, H.-MEIXNER, R.-POLLMAN, U.: Respiration in exercising horses. In: Equine Exercise Physiology. Snow, D. H., Persson, S. G. B., Rose, J. R. (Eds). Cambridge, Granta, Burlington Press 1983, p. 7-16.

HÖRNICKE, H. - WEBER, M.-SCHWEIKER, W.: Pulmonary ventilation in Thoroughbred horses at maximum performance. In: Equine Exercise Physiology 2. Gillespie, J. R., Robinson, N. E. (Eds), Davis, ICEEP Publications, 1987, p. 216-224.

HUSCH, H.: Verhalten der Atemgrößen von Pferden in Abhängigheit von Gangart und Laufgeschwindigkeit. Diplomarbeit. Hohenheim 1974, $68 \mathrm{p}$.

KARLSEN, G. G. - NADALJAK, E. A.: Gazoenergetičeskij obmen i dychanie u rysakov pri rabote. Konevodstvo i konnyj Sport, 11, 1964: 27-31.

LITTLEJOHN, A.-BOWLES, F.-ASCHENBORN, G.: Cardiorespiratory adaptations to exercise in riding horses with chronic lung disease. In: Equine Exercise Physiology. Snow, D. H., Persson, S. G. B., Rose, J. R. (Eds). Cambridge, Granta, Burlington Press, 1983, p. 33 - 45.

McMIKEN, D. F.: An energetic basis of equine performance. Equine veter. J., 15, 1983: 123-133.

MEIXNER, R.: Zusammenhänge zwischen Atmungsgrößen und Bewegungsmechanik beim Pferd in verschiedenen Gangarten. Zulassungarbeit. Hohenheim 1976, 86 p.

MUIR, W. W.-MOORE, C. A.-HAMLIN, R. L.: Ventilatory alterations in normal horses in normal horses in response to changes in inspired oxygen and carbon dioxide. Amer. $J$. veter. Res., 36, 1975, 155-159.

MANSMANN, R. A.-CARLSON, G. P.-WHITE, N. A.-MILNE, D. W.: Synchronous diaphragmatic flutter in horses. J. Amer. veter. med. Assoc., 164, 1974: 265-270.

PELLETIER, N.-BLAIS, D.-VRINS, A.-ROBINSON, N. E.: Effect of sub-maximal exercise and training on dead space ventilation in the horse. In: Equine Exercise Physiology 2. Gillespie, J. R., Robinson, N. E. (Eds). Davis, ICEEP Publications 1987, p. 225-234.

PERSSON, S. G. B.: Evaluation of exercise tolerance and fitness in the performance horse. In: Equine Exercise Physiology. Snow, D. H., Persson, S. G. B., Rose, J. R. (Eds). Cambridge, Granta, Burlington Press 1983, p. 441-457.

POOLMANN, U.-HÖRNICKE, H.: The respiratory dead space of the horse during exercise measured telemetrically. In: Biotelemetry VI. Sansen, W. (Ed). Leuven 1984, pp. 129-132.

POOLMANN, U.-HÖRNICKE, H.: Characteristics of respiratory airflow during exercise in horses with reduced performance due to pulmonary emphysema or bronchitis. In: Equine Exercise Physiology 2. Gillespie, J. R., Robinson, N. E. (Eds). Davis, ICEEP Publications 1987, pp. $760-771$.

TAYLOR, C. R.-HEGLUND, N. C.: Energetics and mechanics of terrestrial locomotion. Ann. Rev. Physiol., 44, 1982: 97-107.

TAYLOR, C. R. - HEGLUND, N. C.-MALOIG, G. M. O.: Energetics and mechanics of terrestrial locomotion. I. Metabolic energy consumption as a function of speed and body size in birds and mammals. J. exp. Biol., 97, 1982;21-31. 
THOMAS, D. P.-FREGIN, G. F.: Cardiorespiratory and metabolic responses to treadmill exercise in the horse. J. appl. Physiol., 50, 1981: 864-868.

THOMAS, D. P.-FREGIN, G. F.-GERBER, N. H.: Cardiorespiratory adjustments to tethered-swimming in the horse. Pflüger's Arch. ges. Physiol., 385, 1980; 65-70.

WASSERMAN, K.-WHIPP, B. J.: Exercise physiology in health and disease. Amer. Rev. Resp. Disease, 112, 1975: 219-249. 